\title{
When Education is Unequal
}

\section{Miranda Greenstreet}

\section{Introduction}

As in many developing countries the majority of urban dwellers in Ghana earn their livelihood not in the formal sector of the economy but in the informal sector, in small-scale non-farming activities. With the urban population continuously increasing at the same time as a worsening of the national economy, the informal sector continues to be the single most important income-earning area, particularly for women.

This article will analyse the extent to which it is the inter-relationship between lack of formal educational skills, and the great importance given to motherhood which helps to push women into the informal sector in general and into market trading in particular. In so doing, it is hoped to clarify some of the characteristics of differential patterns of access to economic and social resources between men and women.

\section{The Education of Girls in Ghana}

The Ghanaian educational system is in principle designed to serve girls and boys equally. The official policy therefore provides no special academic programmes for males or females at the primary school level, with schools open to everyone. However, this potential equality does not mean equal participation.

In spite of state principles, above primary level the curriculum in Ghanaian schools divides the practical subjects into those suitable for girls and those suitable for boys, thus, even during adolescence boys and girls are faced with different expectations of human potential based on a concept of gender difference. As a result, women are likely to be increasingly channelled into secondary jobs, mainly as a result of their limited access to education and training.

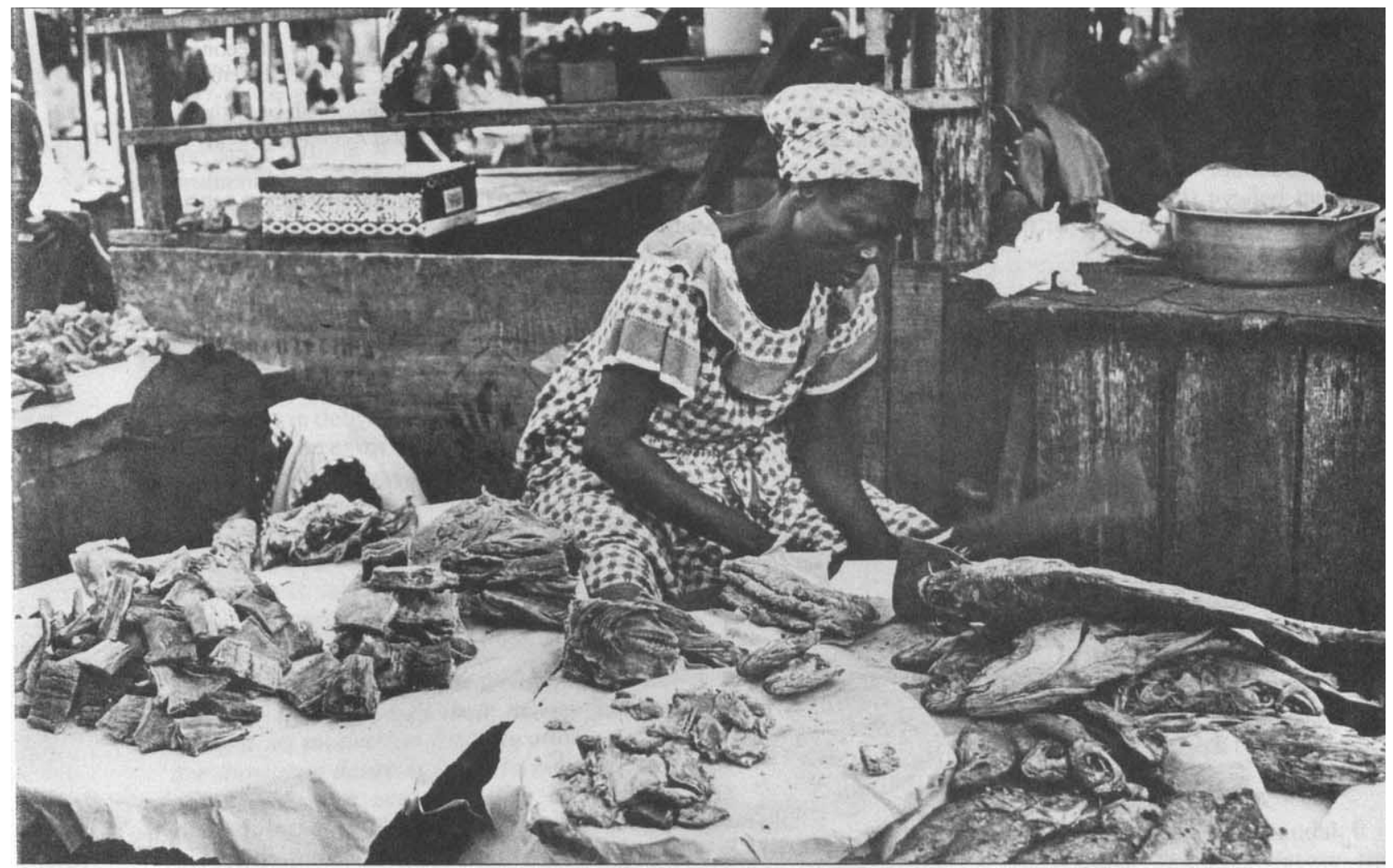

Takoradi market, Ghana

Bulletin, 1981, vol 12 no 3. Institute of Development Studies. Sussex 
Many factors influence the sexual division in Ghana, moulding the attitudes of both sexes. The conviction that higher education is not as important for women as it is for men is reinforced by the motherhood myth which is as strong in Ghana today as it was in traditional society, and promotes as the desired objective of adulthood that a woman should marry, have children and accept the traditional role of wife and mother. This view, which is changing only very gradually, is not only held by men but also by an unusually high proportion of women.

The sex-role pattern is reinforced by parents, friends, teachers, administrators and the media, and has caused differences in the behaviour of the two sexes, to the advantage of the males, regarding education. The lack of lucrative job opportunities as well as the low level of remuneration of women workers acts as a deterrent to families to invest for long periods in the education of their daughters. The attitude of most parents is based on the belief that education is primarily vocational. It is argued that because women are not expected to get high level employment, there is no need to give them higher education. Thus because their educational qualifications are low, their job opportunities are restricted and they find it difficult to get well-paid work. Despite growing pressure to improve the socio-economic status and opportunities of women, which in recent years has led to a more equitable distribution of educational and training resources between the sexes, the dominant view remains that priority should continue to be given to boys. This is buttressed by the fact that women strive to get married as soon as possible, yet when a girl goes to the university she is likely to remain single longer than her non-graduate sisters. Thus, while marriage is not a barrier to a man continuing his education through university, it often constitutes an insurmountable obstacle to the furtherance of a woman's education. However, even if it is assumed that the ideal role for a woman is that of a wife and a mother, education at all levels is still important for her, since the general pattern is for women to remain economically active in their own right after marriage. Women are expected to have their own source of income and assume part of the burden for the support of the household by providing for their own material needs as well as those of their children.

\section{Women's Employment}

Discrimination against women exists not only in education but also in employment opportunities. Lack of training and practiccal on-the-job experience has meant that employers tend to regard women as having inherently lower levels of productivity and job commitment than men. They discriminate against women in general and screen workers on the basis of sex, preferring to employ men even when an individual woman seeking employment may have a higher level of education and training.

This occupational discrimination is illustrated in Table 1 which shows employment distribution by selected occupations. It can be observed that in spite of the significant incursion made by women into the modern sector of the economy they still lag behind men in certain key areas, notably high-level professional categories and the skilled trades and craftsmen categories. Thus as Table 1 clearly indicates, in 1973, in high level professional/technical occupations, only in the statistical and university lecturer categories were women found in significant numbers although even here they represented under one-fifth of employees. In many areas, eg engineering, veterinary science, female participation was either nil or minimal. In the administrative category only 4.9 per cent of government administrative personnel were women: as these people are the country's main decision-makers, we can conclude that women's participation in decision-making is negligible. Predictably, in the middle-level professional technical category, female participation was quite high, with women tending to dominate as schoolteachers and professional nurses. Equally, in the administrative and managerial category their participation was generally quite high, especially as receptionists, clerks and punching-machine operators.

During the last two decades, a rapid expansion has occurred in the educational system, with an increasing number of girls receiving education, and an improvement in their position $v i s-a-v i s$ boys in respect of the total number of school places being taken up. Nevertheless, girls are still disadvantaged with regard to employment opportunities, with the difficult employment situation affecting women, particularly those with little or no education, by providing very few job opportunities in the modern sector, where they have to compete to their disadvantage with men.

\section{Women's Employment in Trading}

Traditionally agriculture was the main area in which women worked to achieve self-sufficiency. Trading and commerce were the second most important sectors for women, accounting for 26.8 per cent of female employment in 1960 and 26.1 per cent in 1970 , as indicated in Table 2. Since the ownership of cash-crop farms is mainly in the hands of men, food farming on a small scale is the main type of agriculture open to women. This is tedious and not very profitable. Therefore women in towns who are able to trade prefer not to farm even when they have access to nearby land. Where their income from trading is not sufficient to meet their requirements, they are obliged to continue farming. 
For urban women one difficulty in farming is the high cost of transport to the farms, with each daily trip costing several cedis. If the farmer takes any of her children to help her, additional fares have to be paid, while farms within easy walking distance of the town frequently have their crops stolen. Another factor discouraging town women from farming is the fact that their children, once a source of labour, nowadays are generally at school. Women therefore prefer to specialise in trading, where it is easy to work alone.

table I

Women in selected occupations 1973

occupation female $\begin{array}{r}\text { females } \\ \text { as \% of } \\ \text { total }\end{array}$

HIGH-LEVEL PROFESSIONAL/TECHNICAL

1. Chemists

2. Physicists

3. Physical scientists

$\begin{array}{rrr}53 & 5 & 8.6 \\ 5 & - & - \\ 45 & 1 & 2.1\end{array}$

4. Architects \& town planners

$7(3) \quad 6.4$

5. Electrical \& electronic engineers

6. Mechanical engineers

7. Chemical

8. Metallurgical

9. Air Pilots \& navigators

10. Agronomists

$324-0.0$

11. Medical doctors

$314-0.0$

12. Veterinarians

13. Pharmacists

14. Statisticians

15. Economists

16. Accountants

17. Lawyers

18. University lecturers

$\begin{array}{ll}- & 0.0\end{array}$

19. Civil engineers

$\begin{array}{rlr}5 & - & 0.0 \\ 10 & - & 0.0 \\ 44 & - & 0.0 \\ 478 & 32 & 6.2 \\ 362 & 54(5) & 12.9 \\ 37 & - & 0.0 \\ 179 & 25(2) & 12.2 \\ 144 & 35 & 19.5 \\ 160 & 5 & 3.0 \\ 1,780 & 99(2) & 5.2 \\ 237 & 30 & 11.2 \\ 189 & 40(4) & 17.4 \\ 244 & 3(3) & 1.2\end{array}$

\section{HIGH-LEVEL ADMINISTRATIVE \& MANAGERIAL}

1. Government administrators

2. Managers etc ie general, sales, production etc
2,657

3,215
137

82
4.9

2.4

\section{MIDDLE-LEVEL PROFESSIONAL/TECHNICAL}

1. Technicians: civil engineering

2. Technicians: electrical

3. Draughtsmen

4. Primary \& middle school teachers

5. Professional nurses

6. Book keepers, cashiers \& accounts clerks

$\begin{array}{rrl}910 & 22 & 2.3 \\ 1,126 & 1 & 0.08 \\ 546 & 7 & 1.2 \\ 35,392 & 14,761 & 29.4 \\ 965 & 2,628 & 73.0 \\ 7,029 & 578 & 7.5\end{array}$

MIDDLE-LEVEL ADMINISTRATIVE \& MANAGERIAL

1. Sales \& shop assistants

2. Policemen \& detectives

1,941

14,525

3. Stenographers \& typists

2,632

2,113

4. Government executive officials

5. Correspondence clerks

6. Receptionists \& travel agency clerks

10,415

464

7. Punching machine operators

() indicates non-Ghanaian

Source: Manpower Survey 1973/74-Manpower Division, Ministry of Economic Planning, Accra (unpublished). It was 10+ engaged establishment survey. 
table 2

Distribution of labour force by industry and sex

\begin{tabular}{lrrrr}
\hline Industry & 1960 & & \multicolumn{1}{c}{1970} \\
\hline & male & female & male & female \\
\hline Agriculture & $1,002,300$ & 579,031 & $1,017,997$ & 772,716 \\
Mining & 45,628 & 2,593 & 28,636 & 2,351 \\
Manufacturing & 135,198 & 98,749 & 164,016 & 212,361 \\
Construction & 86,022 & 2,631 & 70,938 & 2,641 \\
Utilities & 14,015 & 174 & 11,769 & 474 \\
Commerce & 95,798 & 275,333 & 67,078 & 368,894 \\
Transport \& & & & & \\
$\quad$ communication & 66,749 & 1,074 & 82,049 & 2,278 \\
Services & 122,255 & 31,833 & 275,348 & 53,411 \\
\hline total & $1,567,965$ & 991,418 & $1,717,928$ & $1,415,119$ \\
\hline
\end{tabular}

Source: Population Census: 1960 vol IV and Unpublished Figures for 1970 Population Census.

Although illiterate and semi-literate women have traditionally found petty trading the most suitable economic activity for them to engage in (because the skills involved in trading are acquired outside the formal school system), trading is not the province of the illiterate alone. For many school leavers without any further specialised trading there are few opportunities for alternative remunerative employment. Ease of entry is also a factor since petty trading does not demand much starting capital, and many traders take over the business from mothers or other female relatives. The starting capital may be a gift or a loan from a friend, relative or funding institution, and depending on how successful they are, traders can generally pay off the loan and own the business completely after a period ranging from two months to a couple of years.

The instability of marriage as well as the laws of inheritance contribute to women's reluctance to work jointly with their husbands, with trading considered by most ethnic groups as a female occupation whose stalls are handed down to female members of the family. Even after marriage the kinship bond is strongly emphasised, the maintenance of separate accounts by husband and wife reflecting the tenuousness of the marriage tie: women must eat, they must supplement their incomes, they must look after the children and they must strive to build up enough capital in case the husband dies intestate. For these reasons, trading figures prominently in their lives.

Young girls follow their mothers to the market, and even school-going daughters tend to be involved in trading on a part-time basis either before or after school and during vacation periods. The age range of these young trainees is between 7 and 15 years. They fill the markets, carrying heavy loads on their heads and hawking anything from matches to plantains, while their mothers sit beside their wares. Most of the adult women work 10 hours a day and find that this income-earning activity can be effectively combined with childbearing and childrearing. Very small children can be carried to the market on their mother's back and looked after at the market, although nowadays some of those who can afford to pay use the facilities of child-care centres and day nurseries.

Traders usually start dealing in farm produce or prepared foods, with the more able ones moving on to higher status commodities like fish, provisions, hardware and eventually textiles. However, mobility from one commodity to another is not easy, with higher status commodities requiring larger outlays. The female traders within one family therefore tend to deal in the same commodities but in different markets or in different parts of the country; they maintain links through an informal information network. Some women in salaried employment or professions also engage in trading but they tend to concentrate on light manufactured goods, especially clothing and cosmetics. This type of trader, who is generally seeking greater autonomy in the home, is not the predominant type. As shown in Table 2, by 1970 women accounted for 84.6 per cent of total emplóyment in the commercial sector, however, the bulk of them were in the low productivity areas of trading. In wholesale trading, for example, there were fewer than 1,000 women wholesalers as compared with 8,000 men. While those few women in wholesale trading are relatively wealthy, the majority of women small-scale or petty traders and hawkers are quite poor.

To be successful in trade, but more particularly, the food trade, it is very important to be a regular trader 
and to build up contacts with the suppliers. Those who fail to buy from suppliers during the less profitable months may find difficulty in obtaining produce when there is great demand for it; this is a particularly strong feature of the tomato trade. At the height of the rainy season tomatoes are so plentiful that middle women bringing them to Accra or Kumasi are often forced to sell at a loss. Moreover, at this time the tomatoes rot quickly. Yet traders who fail to purchase under these conditions may find difficulty in obtaining tomatoes later on when they are scarce and fetch a higher profit. Some of the traders buy part (in a few cases, all) of the goods on credit, take them to the town to sell and pay for them when they pick up the next consignment. This type of credit arrangement enables a trader to start work with no more capital than the cost of the baskets and transport. However, to build up a trade of any size it is important to have access to capital and to trade in a consistent and regular manner.

More and more traders are coming to use the modern banking system for savings, in addition to the more traditional system of sus (rotating credit), and of cooperative credit from benevolent societies. Some own durable goods such as sewing machines, transport, farms, houses, jewellry, refrigerators, radios and television sets. Nonetheless the majority subsist by petty trading and cannot achieve real economic independence. Despite this, traders are accused of slipping through the tax mesh and not contributing to national income; consequently, they are now required to register with the Department of Income Tax and pay a modest fee as a trader.

\section{Conclusion}

For most women, trading is not just a skill and an economic necessity but an occupation from which they derive a sense of achievement. In addition to providing the household with income for essential requirements, the burden of educating children, both boys and girls, falls heavily on their mother. Even when the father is alive and fully employed, mothers tend to pay their children's school fees. Furthermore, with the high divorce rate and the fact that men generally do not support the children of previous marriages, women's need for an income is critical. Since women's high expectations cannot be met through employment in the modern sector, regardless of their educational levels, trading is for the majority of them the only means whereby they can fulfil their various functions as wife, mother and income earner.

\section{References}

Bauer, P. T., 1963, West African Trade, Routledge \& Kegan Paul, London

Dunham, D. M., 1974, 'Marketing in Southern Ghana towards a planning typology', Occasional Paper no 47, Institute of Social Studies, The Hague

Ewusi, K., 1974, The Labour Force Participation Rate, ISSER, Legon

Greenstreet, Miranda, 1971, 'Employment of Women in Ghana', International Labour Review, International Labour Office, Geneva

-1981, 'Continuing Education for Women in Ghana', unpublished

Hart, K., 1973, 'Informal income opportunities and urban employment in Ghana', Journal of Modern African Studies

Hodder, B. W., and U. T. Okwu, 1969, Markets in West Africa, University of Ibadan Press

Little, K., 1973, African Women in Towns, Cambridge University Press

McCall, C., 1961, 'Trade and the role of the wife in a modern West African town', in A. Southall (ed), Social Change in Modern Africa, Oxford University Press for The International African Institute, London

Nypan, Astrid, 1960, 'Market trade: a sample study of market traders in Accra', Research Division, University College of Ghana

Pauline, Denise, 1963, Women of Tropical Africa, (trans. H. M. Wright), Routledge and Kegan Paul, London

Sai, Florence, 1971, The Market Woman in the Economy of Ghana, MS Dissertation, Cornell, unpublished. 